\title{
Mikrobiologiese kwaliteit en veiligheid van vars produkte: Rede tot kommer?
}

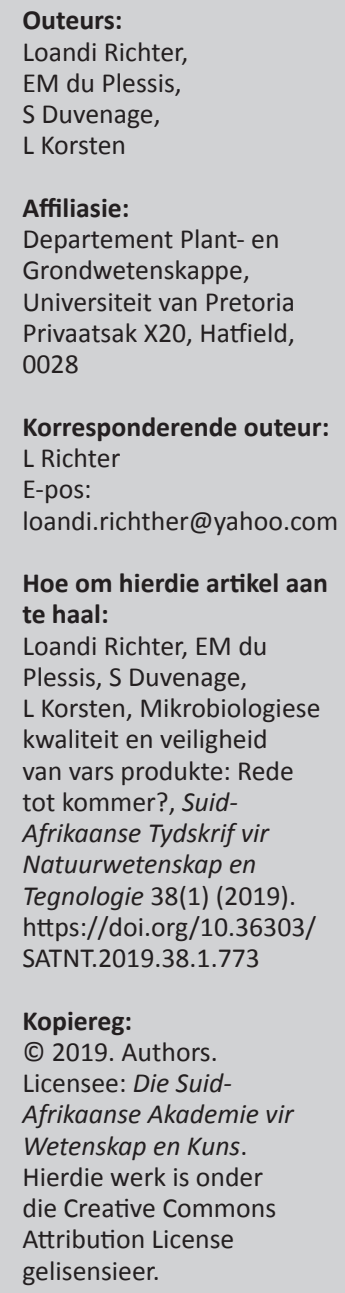

Korresponderende outeur: L Richter

E-pos:

loandi.richther@yahoo.com

Hoe om hierdie artikel aan te haal:

Loandi Richter, EM du

Plessis, S Duvenage,

L Korsten, Mikrobiologiese kwaliteit en veiligheid van vars produkte: Rede tot kommer?, SuidAfrikaanse Tydskrif vir Natuurwetenskap en Tegnologie 38(1) (2019). https://doi.org/10.36303/ SATNT.2019.38.1.773

Kopiereg:

(C) 2019. Authors. Licensee: Die SuidAfrikaanse Akademie vir Wetenskap en Kuns. Hierdie werk is onder die Creative Commons Attribution License gelisensieer.

Microbiological quality and safety of fresh produce: Reason for concern?: Fresh produce related foodborne disease outbreaks have increased globally. Contamination of fresh produce with multidrug-resistant human pathogenic bacteria occurs during production, distribution and sales. The global antibiotic resistance threat emphasises the importance of characterising and tracking antimicrobial resistance in the water-plant-food public health interface.

In Suid-Afrika word vars groente deur kommersiële kleinhandelaars en straatverkopers, asook by boeremarkte, verhandel. Landbou-uitvoere speel ' $n$ kernrol in die Suid-Afrikaanse ekonomie. Daar word toenemend na ander Afrikalande, asook na Asië, Europa en die MiddeOoste, uitgevoer. Dit sluit uitvoere, verantwoordelik vir $13.6 \%$ van die ekonomiese groei in die kategorie "plantmateriaal en groenteprodukte", in. Die positiewe verband tussen 'n voldoende inname van vars groente en 'n gesonde leefstyl vind wêreldwyd aanhang.

Die toenemende aanvraag na vars produkte hou direk verband met die toename in voedseloordraagbare siektes. Mikrobiologiese kontaminasie van vars groente kan in enige van die voor- en na-oesstappe gedurende prosessering plaasvind. Dit sluit die besproeiingswater, grond, mense wat die produkte hanteer en die oppervlaktes waarop die groente verwerk word, in. Die feit dat menslike patogene vir lang tydperke op groente en vrugte kan oorleef en dat onaanvaarbare hoë vlakke van mikrobiologiese kontaminasie in Suid-Afrikaanse besproeiingsbronne gerapporteer word, beklemtoon die belangrikheid daarvan om voedselveiligheid te verseker.

Die gram-negatiewe bakteriële familie, Enterobacteriaceae, sluit sowel voedseloordraagbare menslike patogene as natuurlike saprofiete in. Die voorkoms van voedseloordraagbare patogene is egter nie meer die enigste bron tot kommer nie. Onlangse studies toon dat die verspreiding van antibiotika- weerstandbiedende organismes toenemend ' $n$ openbare gesondheidsrisiko inhou. Groentesoorte wat rou geëet word, is moontlike draers van dié antibiotika-weerstandige Enterobacteriaceae. 'n Sterk korrelasie tussen besproeiingswaterbronne en die teenwoordigheid van patogene op vars produkte is reeds voorheen gerapporteer. Die organismes vanaf die waterbronne is dikwels boonop weerstandig teen verskeie tipes antibiotika. Navorsing wat antibiotika-weerstandbiedende organismes in varsproduktekettings identifiseer en karakteriseer, kan dus 'n belangrike bydrae lewer om die risiko waaraan die verbruiker blootgestel word, te bepaal.

'n Wêreldgesondheidsorganisasie-feiteblad oor antibiotikaweerstandigheid het onlangs die ontnugterende werklikheid uitgelig dat weerstand teen antibiotika vandag een van die grootste bedreigings vir wêreldwye gesondheid inhou. Spesifieke bakteriële ensieme veroorsaak dat selfs nuwe-generasie-antibiotika nie meer doeltreffend gebruik kan word as behandeling vir weerstandige patogene nie. Alhoewel min navorsing voorheen hierdie aspek ondersoek het, is die teenwoordigheid van hierdie bakteriële ensieme in bakterieë wat groente besmet reeds bevestig. Die teenwoordigheid hiervan in vars produkte wat in beide die formele en informele markte van Suid-Afrika verkoop word, is egter onbekend.

Hierdie studie het op die mikrobiologiese kwaliteit en teenwoordigheid van weerstandige Enterobacteriaceae op vars produkte vanaf verskillende kommersiële kleinhandelaars, straatverkopers in informele nedersettings en boeremarkte gefokus. Verder is potensiële

Nota: 'n Seleksie van referaatopsommings: Studentesimposium in die Natuurwetenskappe, 25-26 Oktober 2018, SA Akademiegebou, Pretoria, Suid-Afrika. Gasredakteurs: Prof Rudi Pretorius (Departement Geografie, Universiteit van Suid-Afrika); Prof Chris Swanepoel (Departement Besluitkunde, Universiteit van Suid-Afrika); Me Andrea Lombard (Departement Geografie, Universiteit van Suid-Afrika) 
kontaminasiebronne van volledige produksiekettings van drie verskillende spinasieproduserende plase - vanaf die plaas tot by die handelaar - ondersoek. Hoë vlakke van weerstandige potensiële patogene is gevind in isolate vanaf vars produkte by die verskillende handelaars, asook in die kettings vanaf die waterbron, en voor- en naoesprosessering.

Hierdie is die eerste studie wat die teenwoordigheid van bakteriële ensieme, wat selfs nuwe-generasie-anti- biotika teenwerk, ondersoek in vars produkte wat in verskillende ekonomiese groepe verhandel word, asook in die volledige kommersiële kettings verantwoordelik vir uitvoere. Die resultate beklemtoon die noodsaaklikheid om die mikrobiologiese kwaliteit en potensiële bronne van kontaminasie in vars produkte te identifiseer, asook om 'n bewustheid van die noodsaaklikheid van waterhigiëne te kweek. 